\title{
Vanini in England
}

$\mathrm{O}^{\mathrm{F}}$ the foreigners who visited England in the reigns of Elizabeth and James I perhaps the most interesting figures are those of Giordano Brono and Ginlio Cesare Vanini. Although it would be absurd to place the lacubrations of Vanini on a level with the philosophical, if not always intelligible, speculations of Brano, yet the similarity of the subject matter of their audacious writings, their wandering and adventurous lives, and perhsps most of all the similarity of their tragical fate, make us constantly link their names together, and perhaps have contributed to shed upon Vanini some sparks of the halo which surrounds the name of Brano. We have hitherto had no contemporary account of the visit of either to our shores. We have known only what they themselves have been pleased to tell us in their works -in the case of Bruno a mirture of 'Wahrheit und Dichtung' which excites in us a desire to know how the matters recorded appeared to those eminent persons-Sir Philip Sidney and Fulke Greville among others-with whom it seems to be clear that during his visit be was intimately associated. But Vanini tells us hardly anything of his risit except that he pessed two years in England, that his zesl for the catholic faith occasioned his imprisonment for forty-nine days, and that he was prepared to receive the crown of martyrdom with all the zeal imaginable. ${ }^{1}$ There are, however, among the State Papers in the Record Office a number of letters, two by Vanini himself, others by those with whom he was immediately connected whilst in England, which give us a tolerably detailed account of his residence in this country, and throw an important though not altogether favourable light upon his life. his character, and his opinions.

Among the sources of information for the reign of James I, the

I Amphitheatram Altemas Providentian, pp. 117-18. Bat he is not rery scenrate in his atatement, and implies-if he does not actally asest-that he came to England on a relifions mission:-Ego sane ool minimus militantis Ecclevian Tyro, cum arno pranterito Londiri ad agonem Chrietianem destinatus assem, adooque 49 diobus

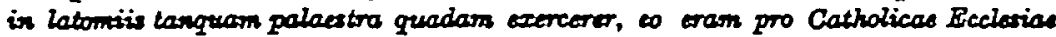
authoritate defonsanda effundandi saxguiris doridorio acconsus, of irflommatus, ut mihi a Doo immortali vel majus donum, aut melius contingere nullo modo potuistet, ita quidem si nen stperiorem, inferiorem certe nullo marlyre proprias conscinatias lestinoniem me indicavit at confratrum, qui mecums in codom eront Xisto at thactro forticrimi ef digui sare qui tale Deo spectaculum exhiberent. 
latter part of Elizabeth, and the first years of Charles I, an important place must be given to the correspondence between Sir Dudley Carleton-8fterwards Visconnt Dorchester-successively ambassador at Brassels. Venice, and The Hague, and John Chamberlain. Chamberiain, well described by Mr. Thompson Cooper in the 'Dictionsry of National Biography' as 'an accomplished scholar and an admirable letter-writer, the Horace Walpole of his day,' during more than a quarter of a century was in the habit of writing long and frequent letters to his friends, especially to those who filled diplomatic appointments abroad, foll of interesting details, including not only public events, but all the court gossip of the time. A private gentleman of good position and ample fortune, intimste with many men of eminence, and miring in the best society of his time, he seems to have been singularly free from ambition, and to have desired neither place nor money. Copies (now in the British Museum) of a large number of his letters, made a century and a half since by Dr. Thomes Birch from the originals in the Becord Office, form the principal and by far the most interesting part of two works entitled 'The Court and Times of James I' (2 vols. London, 1848) and 'The Court and Times of Charles I' (London, 1848). A volume of his letters written in the raign of Elizaboth has been printed by the Camden Society. Many others are to be found in Nichols's 'Progresses of James I,' and in Sir Balph Winwood's 'Memorials.' A considerable number of Chamberlain's letters, however, are still in the Record Office and unprinted, many of these being ss full. of interest as those which have appeared in the volumes just referred to.

In the 'Court and Times of James I' there are several letters from Chamberlain and one from Carleton referring to two Carmolite friars professing to be protestents, who came to England from Venice in 1612 with an introduction from Carleton to Archbishop Abbot, by whom they were for some time entertained at Lambeth. Their names are not given, but in the published 'Calendar of State Papers,' besides many other letters not printed in the 'Court and Times of James I,' are two letters in Italian from one of them called in the Calendar Julio Cesare Vandoni ; one to Carleton thanking him for the introduction to Archbishop Abbot, the other to Iseace Wake, then Carleton's secretary. The name certainly at first sight looks much more like Vandoni than Vanini, but on a comparison with the only other specimen of Vanini's handwriting known to erist-the osth taken by him on receiving the degree of Doctor, which has been brought to light from the Archives of the University of Naples by Professor Bettembrini, and a facsimile of a part of which is given by Signor Palumbo in the book hereinafter referred to-the ' $n$ ' forming the third letter of 'Vanini' in the signature of the letters to Carleton and Wake will be seen to be identical with 
the letter ' $n$ ' in the word 'spondeo' in the oath, and to have the same flourish resembling a ' $d$ ' at the end of it, whilst other similarities show that the handwriting of the osth and of the two letters is identical. That these two letters were written by Vanini and that the State Papers contain several references to his visit to England was first made known by Signor Raffaelle Palumbo in 1878, in a brochure of one hundred pages entitled 'Giulio Cesare Vanini e i saoi tempi, Cenno biografico-storico corredato di documenti inediti' (Naples). The object of this book, the anthor tells as, ' is to make known some docaments discovered by me in London in the Archives of the State. These documents, which have remained unknown for three centuries, ensble us to understand both the character of and many details respecting Giulio Cesare Vanini, who died at the stake at Toulouse and was one of the last of the philosophers of the Italian Renaissance.' Signor Palumbo is entitled to mach credit, und ought to receive our gratitude, for the discovery that these documents refer to Vanini, but unfortunately he has made but little use of them in his book. He prints in full, indeed -though not quite correctly - the two letters in Italian from Vanini himself, which are really among the least interesting of the whole series, but of those of Archbishop Abbot and John Chamberlain, to which he refers, he gives very brief extracts and incorrect summaries. He was evidently anaware that several of these letters had been printed, and it is clear that he had only actually read the two written by Vanini, and that he was entirely ignorant of the existence of some of the most important of the rest, whilst he has contented himself with reading the summaries of the others giren by Mrs. Green in the 'Calendar of State Papers.' On several important points-possibly from a want of familiarity with our language and our history - he has misunderstood and misskated the effect of these summaries, and has thus deprived his narrative of any value whatever, either for the details of Vanini's residence in England, or for enabling us to form any conclusions as to his character or his object in visiting this conntry. ${ }^{2}$ Moreover, of the nineteen letters which I have been able to find in the Record Office relating to Vanini and his risit, Palumbo refers only to ten, and has not even noticed perhaps the most important of all-one from Archbishop Abbot to Sir Dudley Carleton, written 16 March 1614.

\footnotetext{
2 Gignor Palumbo's ineocuracies are not confined to English sefriss. Ho speaks of Bajie (wbo wes born in 1618) 28 a contemporary of Vanini, and states thet Gramond the historian was president of the parliement of Toulouse at the time of Vanini's arecution, thet he presided at the trial and suborned the chief witness against him, Francon by name. Brotally as Gramond trents Vanini in his Hislory, it is only just to him to say that he was in no way concerned in the trisl. It wes not until some years later that he sucoeded his tather, with whom he hes been confounded, in the office of President des Enquetes in the parlinment of Toulousn. But though his father then hold that office, there is no evidence that he, anj more than his son, took part in the trial of Vanini.
} 
Signor Palumbo's work was reviewed by Professor Fiorentino in the 'Nuova Antologia' for September 1878, but so little attention did it receive in England that no copy of it is to be found in the British Museum, nor has it, or the remarkable discovery made by Signor Palumbo, so far as I know, been noticed by any English priter except the Rev. J. Owen, who in his recent work, "The Skeptics of the Italian Renaissance,' has devoted several pages to Vanini's visit to England. But unfortunately Mr. Oren has not consulted the documents themselves, or even the printed calendars, and has merely based his account upon that of Palumbo, or rather, perhsps, upon Fiorentino's article in the 'Nuova Antologia,' borrowing all the Italian author's mistakes, and adding one or two of his own. He, like Palumbo, is entirely ignorant of the fact that several of the letters have been printed in "The Court and Times of James I.' Both writers take a very favourable view of the character of Vanini, and neither of them has extracted from the letters any of the passages which tend to give an opposite impression. Each of them represents Vanini as a sincere and conscientions man, an orthodox but liberal-minded catholic, hoping to find in the Anglican Charch greater intellectual freedom than in the Roman communion, and returning to the church of Rome when he found that of England not more bat less liberal and giving less opportanity for freedom of thought. This is certainly not the impression the letters themselves give as. Mrr. Orren's chapter on Vanini is, notwithstanding, one of the most interesting in his book, and it is grestly to be regretted that he has missed the opportanity of making himself acquainted with the facts as to Vanini's stay in England, and of giving them to the world. They would certainlyafter making all allowance for the narrow-minded prejudices of Archbiahop Abbot-have obliged him to modify his opinion of the character of Vanini, and to have represented it less farourably.

Lacilio, or, as he preferred to style himself, Ginlio Cesare Vanini (perhaps copying a man for whom he more than once expresses great admiration, Julius Casar Scaliger), was born at Taurisano, near Otranto, in the kingdom of Naples, in 1585. His taste for learning induced his father to send him to the university of Naples, where he took the degree of Doctor utriusque iuris in 1606. Philosophy and physical science were his two farourite sabjects of stady, and his two masters were, as he tells as, John Bacon (i.e. Baconthorpe), ' the prince of Averroists, from whom I have learned to swear only by Averroës,' and Pomponstius, whose book 'De Incantationibus' he styles ' a golden book,' and of whom he writesstrangely enough, since Pomponstius was an opponent of Arerroës and a disciple of Alezander of Aphrodisias- " that Pythagoras would have said that the soul of Averroess had passed into the body of 
Pomponatius.' Renan, in his 'Averroès et l'Averroïsme,' seems hardly as fair as usual in attributing to Vanini a deliberate falsehood in this statement as to his masters, one of whom died two hundred and forty years and the other fifty years before his birth; and I agree with Mr. Owen that he only incended to express the obligations he was under to the works of these two philosophers, and not to suggest that he had actually been their pupil. His other favourite authors were Aristotle, Albertus Magnus, and Jerome Cardan. For the details of his life between June 1606, when he took his doctor's degree, and the spring of 1612, when we find him in Venice, we have only the scattered references to be found in his two ertant books, the 'Amphitheatrum Aeternae Providentiae,' printed at Lyons in 1615, and his 'De ddmirandis Naturae . . Arcanis,' printed at Paris in 1616. That he became a Carmelite friar, and received priest's orders; that he studied for some time at Padas and there (probably) made the acquaintance of a fellow student, one Giovanni Maria Genochi ' ; that he travelled through Germany, having there Genochi as his companion, Bohemis, Holland, and Switzerland, disputing with atheists and protestants, and alwrajs professing himself to be an orthodor catholic; then for a time staying in Franco-probably in Paris, but (perhaps) driven thence by the false accusations of a certain Henricus Sylvius-is really all that we know of his history during these years. In the spring of 1612 , then in the twenty-seventh year of his age, we find him at Venice, and it is there that our special interest in him in connexion with his English visit begins.

It appears from the letters which I shall shortly quote at length, that in or shortly before March 1612, Sir Dudley Carleton, then ambassador to Venice, and his secretary, Isaac Wake, had made the acquaintance of two Carmelite friars, men of considerable learning, who professed a secret attachment to the reformed doctrines and a desire to visit England. Carleton, who though a shrewd diplomstist was now at least a zealous protestant-he had been sospected of being a Roman catholic in his youth-was convinced of their sincerity: "Their discovery of light even in the midst of darkness hath been very miraculous.' Accordingly he wrote to Archbishop Abbot, recommending them to him, and receired from him a reply to the effect that if they visited England they would be well received. These letters I have not been able to find, but it seems from a letter of Chamberlain to Carleton of 17 June 1612, that, notwithstanding the desire as well of Carleton as of the two friars themselves that their visit 'should be with all secrecy,' the matter had not been kept private bat had been talked of two months before their arrival: "They were expected long before thes came, and the

\footnotetext{
- Varioualy called by the biographers of Vanini, Genochi, Gennochis, Gainnochi,
} and Binnoohi. 
bishop of Ely [Andrewes] could tell me two months since that two sach were on their way . . . some while before they set forth.'

One of these friars was Vanini, the other-the younger of the two-called himself Giovanni (Battista?) Mraria de Franchis." They would seem to have started from Venice soon after April 29, furnished with a letter of introdaction of that date from Carleton to Chamberlain, who had accompanied him on his embassy to Venice in 1610, and hed lately (in November 1611) returned to England. 5

Good Mr. Chamberlain,-You must be content to be troubled sometimes with commissions from your friends with which variety will male the quietness you enjoy so much the more pleasing. This that I now recommend to you is a work of charity to be assistant to two honest strangers, who were yet vever nearer England than this place nor never spake with Englishman but with myself and some of my house : and jet as they are carried thither by their affection, so are they well settled in our religion. For this cause I have recommended them to my Lord Archbishop's grace, by, whom I hare good assurance they will be well received : and because it is difficult for strangers to find access, I will desire this of you: if you are known to my Lord to bestow the conducting of them yourself; if otherwise to address them to some one of his chaplaing whom you hesi to bo of most trust about his Lordship for as their mission hath been with all secrecy, so I desire their reception may be. And as their discovery of light even in the midst of darkness hath been very miraculons, so those good parts of learning that are in them I promise myself will add mach to the bright shining thereof through all the world. Of their outward appesrance and manners you must respect no more than of those who have always lived in cloisters but their ingenuity will (I assure myself) give you the same satisfaction it hath done me. Their course of life you shall more particularly nuderstand from themselves: and I pray you as for their first access so likewise for their other occasions let them be aided hereafter by your friendly advice: and as I shail be glad to have from you what satisfaction they both give and receive so where they will write I pray you to give their letters conveyance. And thas with wonted good wishes I commit you to God's holy protection. From Venice this 29 of Aprill, 1612.

Of the two friars' journey from Venice to London we have no detsils, though it is not impossible that some of the adrentures and

- Whether he is the same parson with Giovani Merie Genochi I shell consider later on.

- Signor Palumbo, as a foreigner, may be arcused for knowing nothing of Chamberain, bat it is strange that Mr. Owen should here teiled to identify Cerleton's correspondent-a men well known to every student of the reigas of James I and Charles I, whose lattars, especially those to Carleton, are so trequently quoted by our historians and biographers. Signor Palombo and Mr. Owen both erroneously. and strangely describe him as Mayor of Carterbury, an office which he never flled, having, indeed. no connexion phaterer with that city; and Mr. Owen adds to the blunder of Signor Palumbo by knighting him and describing bim as 'Sir somebody Chamberlain.'

- Cal. St. P. Dom. Ser. Jae I, 1611-18, Lriii. 127, No. 103. Printed in Court and Times of James $I$, p. 105. 
conversations which Vanini records as occurring in Germany, France, Holland, or Switzerland, may have taken place on this occasion. Fuhrmann ${ }^{7}$ seems to have thought that he went to England by way of Paris, and, as well as others of Vanini's biographers, that his visit to this country was occasioned by some hostile proceedings on the part of one Henricus Sylvius, of whom he more than once speaks with much bitterness. Mr. Owen also writes : 'Driven out of France by the malevolence of a certain Enrico Sylvio [sic] we next find Vanini in England.' But I do not understand Vanini's words as necessarily implying this. Speaking of the different meanings or applications of the word 'fatale,' he writes: : Altorum versatur circa exiliora, veluti dicam, fatale mihi frit ut ab Henrico Sylvio iniustissime laesus Britanniam inviserem. Dr. Ernst Münch ('Julius Cäser Vanini : sein Leben and sein System ') says that Vanini took ship for England at Harre, but I have failed to find any authority for this statement. The two friars arrived in London (not Canterbury as Signor Palumbo and Mr. Owen strangely imply) shortly before 17 June, ${ }^{9}$ on which day Chamberlain wrote to Carleton a long letter containing all the news of the day, from which the following is an extract:

'My very goode Lord : yor two Carmelites are come, and have delivered me $\mathrm{yo}^{\circ}$ letter of the $29^{\text {th }}$ of Aprill, I have since received a letter of the 22 of May. Touching yor frisrs yt was my chennce to be out of torne when they came and they unwilling to loose any time found accesse to the archbishop in my sbsence, wch came very well to passe, for I ahold hsve proved but a bed conductor, haring no manner of acquaintance in that house but Mr. Bobert Hatton who is stoward : neither I tell wherein to pleasure them more then in conveying theyre letters which I send here inalosed whereby you shall recere from themselves a full relation of theyre present estate. They are now lodged at Lambeth in the bishop's house where the elder of them is still to remain, the other is to be sent shortly to the arehbishop of Yorke by the king's appointment though I thinke he had rather have continued in these parts yf he might have been permitted. Theyre reception could not be so private as yt seems you wished for they were expected longe before they came and the biahop of Ely could toll me two months since that there were two such upon the wry, wit yt seemes was some while before they set foorth. He told me likewise the other day of a certain bishop in the venetian territorie (but he had forgot his name) that is writing a worke against the Popes usurping jucisdiction. To tell you freely my opinion as far as I understand this business, though ft cannot be denied bat that you have done a very goode and charitable warke in reducing these straginge sheep,

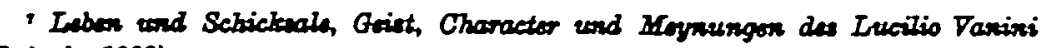
(Loipsig, 1800).

- Arqhithactrum, Br 48, p. 285. Bousealot, Guores philosophiquas de Varini, p. 166, states that this Sylvius wes an alehemint who was put to death tor his crimes at tho time thet Venini wes in Frence.

- It is clear that thoy did not arrive until aftor 11 Juno, as an that day Chamberlain bad written to Carleton without anj mention of them. 
yet I donbt you wil reape no great thankes on either side, for I find our bishops here not very fond of such guests, and thinke they might hsve enough of them, yf they could provide them maintensnce so that unless they be very eminent and men of marke they shall find little regard after a small time. ...10

Their abjuration of the Roman catholic faith and their reception into the reformed Italian church took place on Sunday July 5, at the chapel of Mercers' Hall, then used as the place of worship of the Italian protestants, of which Ascanio Spinola was the minister. ${ }^{11}$ Unfortunstely for us, Chamberlain was not present, but he gives the following account of the matter to Carleton in a letter dated 12 July 1612 :

My very goode Lord: yor two Carmelites made a publike confession of theyre fayth and conversion wh an abjuration of theyre former errors on Bunday last at the Italian Church in the pressenc3 of a great assemblie, whereof ar Francis Bacon was the man of most marke. I was not there by the error of my man whom I sent to learne and he brought me worde the appointment held not that day : but I understand the elder acquitted himself best in point of learning and the other in language, as likewise he hath the voyce of my L. of Cannterburie's house of the more prompte and quicke spirit and they wish that they might kepe them both still, or yf they must part w $^{\text {th }}$ one that they might retain him. . . .12

It appears from a sabsequent letter of Archbishop Abbot, in which he refers to the younger friar as the one that afterwards went to York, that Vanini was the one here referred to as the elder, and

- Oat. Lrix 185, Na 71; Cower and Times of James I, i. 173.

"II I heve been mable to find any socount either of Ascanio Spinols or of the Italien church in Iondon (as reconstituted in $160^{\circ}$ ) prior to the arrival of the archbishop of Spaleto in I616. The only notice of them with which I em soqueinted is conteined in

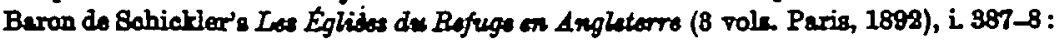

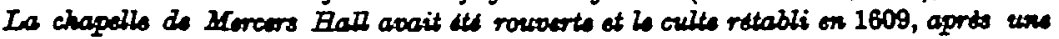
longue intorreption, par un arcion moine vense de Bruselles, Aseario Spinala, anoc

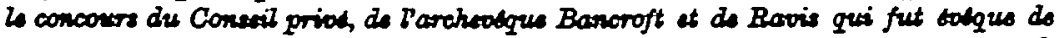
Londres de 1607 d 1609 . Mais, aivisi qu'il son plaignait au convistoire flamused,

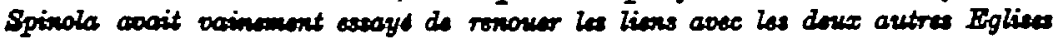
thanghes: it avait domands d plusieurs reprises d M. Burlamachi de parior anx

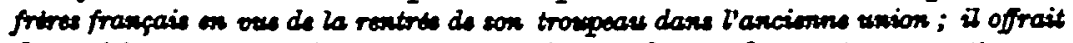

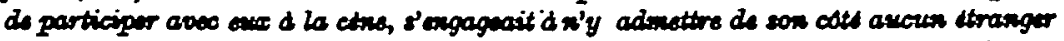

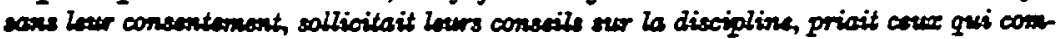

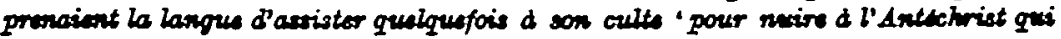

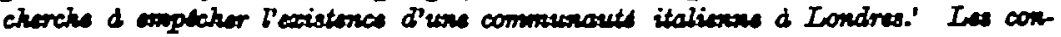
sivtoires flasmand et frangais persistiront dans lour abstontion, justifik biontat par is

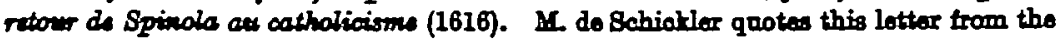
Menoirs of Bimon Brytirck, poblighed (in Dntah) by the Marnix Vereeniging (Otrooht, 1873). Aseanio Spinole seems to have lett Englend about the time of the errival of the archbishop of Spaleto, who sueceeded bim es minister of the Italien abureh, for Chemberisin writes to Carloton on $18 \mathrm{Jan} .1617$ : 'Here is a romorr that tho Itelien presoher, $\Delta$ scanio, is ron amay ; being, 28 is seid, enticed by ono Grimaldi,

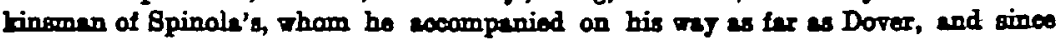
his wito nor triends have no nows of him ' (Conet and Times of Janes I, p. 389).

13 Cal. lex 186, No. :; Coust and Times of Jamea I, i. 178. 
it appears that he made himself less agreeable and produced a less favourable impression upon the members of the archbishop's household than his younger colleague, though he was the more learned. It is probable that their sermons at the Italian church referred to in the next letter would be on Sunday $19 \mathrm{July}$, for before the 23rd the two friars had accompanied the archbishop by his invitation to his summer palace at Croydon, and from that place they mrote to Carleton, as appears from a letter of that date from Chamberlain to Carleton enclosing the friars' packet, the contents of which, howerer, are not among the state papers.

Yor two friers are gon thether [Croydon] $\mathrm{w}^{\text {th }}$ him [the archbishop] and are not yet otherwise disposed of: they have both preached of late at the Italian Church $w^{\text {th }}$ reasonable approbstion. Here is a packet from them whe I send as I received yt from Mr. Wimark to whom yt was delivered (as he sayes) in the dark from Dick Martin, and thinkeinge it to be somewhat concerning himself opened it before he was aware but finding what it was protests he sought no secrets in it.13

We have aiready seen from Chamberlain's first letter that by the king's appointment one of the friars was to be sent to the archbishop of York, and the younger, Giovanni Maria, was chosen. He accordingly started for Bishopsthorpe on or abont 23 July, furnished with a letter from Abbot to Tobie Matthew, then archbishop of York. He arrived at Bishopsthorpe on the 27th, and two days later Matthew wrote the following letter to one of the high officers of the court, probably the earl of Suffolk then lord chamberlain, or Sir Thomas Lake who was then performing the duties of secretary of state though not actually appointed to that office.

My very good Lord, -I have thought meet with all convenient expedition to advertise your lo: that Mr. Johannes Maris the converted friar carmelite came hither unto me upon Mondsy last the IIvii of this month accompanied with a letter from the most reverend father my Lord of Cant : his grace, dated the 23 of the same to the effect of that his Majesty's letter which I formerly received from your lordship for entertainment of the said stranger who is and shall be welcome to me not doubting but he will well deserve so to be by his religious and civil carriage whereof I see no eause but to conceive a very good opinion. Thus loath to trouble your Lordship any longer than needs I must and eftsones intreating that my readiness to receive him into my house msy be signified to his most excellent majesty. . . . 14

\section{Your L. ever most assured}

\section{TobIas Eboracensis.}

Bishopsthorpe, 29 July 1612.

1s Cal. 1ra. 188, No. 12.

"Cal lnz 139, No. 16. This letter is not addressed or endorsed, but is deseribed

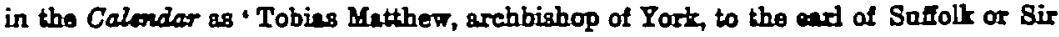
Thow Lake.' 
Though we hardly gather from this letter that Archbishop Matther was very much delighted to receive the guest whom the hing had sent to him, yet it seems from a letter of Vanini to Isaac Wake that he received De Franchis bindly and hospitably.

We hear nothing more of either of the friars for upwards of two months; but then, under date of 9 Oct. 1612, we find two letters written by Vanini himself, one to Carleton, the otber to Isaac Wake his secretary. The following are translations of these letters, which are printed in their original Italian, though not quite accurately, by Signor Palumbo. The first is addreased to Carleton, the second to Wake :

Most illustrions and excellen: Sir,-After I have made my most humble reverence to your excellency, bnowing your affection and anxiety for my welfare I write to inform you how much I am enjoying myself in these parts, and what affection I have for my respected lord the most illustrious archbishop of Canterbury. And it is so much the more pleasant to me that I am sure by showing gratitude to his illustrious and reverend Lordship I am doing what is agreesble to you who have placed me at this court, and since I am not able to render you any recompense I shall alwrys remain your excellency's most obliged servant: to whom I make a profound reverence and pray that you may receive from our Lord all the happiness that you can wish.

From Lambeth, 9 Oct. 1612.

$$
\begin{aligned}
& \text { Di V.S. Il. } \\
& \text { GroLio Cesare Vavant. }
\end{aligned}
$$

Milord,-I owe you a reply to your lordship's letter of last month which owing to my having been until now at Croydon I have not been able to reply to as I ought to heve done.

To give you news of myself, I am well and happy, praise the Lord, and sm treated most affectionately by Monsignor the most illustrious archbishop, who constantly entertains me ai his table and gives me hopes that one day he will confer some office on me.

For three months past my brother Giovanni Maris has been at York at the court of the archbishop, by whom he is liked and treated with much hindness, and he has lately written to me that he is in 80 much favour that he expects to receive a benefice from the archbishop.

Mr. Josias Robinson tells me that he knew your lordship at the University of Oxford.

I have not yet seen Signor Chamberlain, but I shall not fail to go to visit him as soon as possible and to do what your lordship has written to me.

I beg you to let me know if my box or trunk of clothes which I left in the chamber of the chaplain has been put on board ship for London; if not, I beg you to send it to me.

I shall be very glad if any opporturity occurs to be of service to you (as I have been to my lord) by praising the admirable way in which your excellency has behaved in the embassy. 
For the rest I liss your excellency's hands and those of the chaplain, praying for you from our Lord all happiness.

From Lambeth, 9 Oct. 1612

\section{Di V. S. Il'. $^{\circ}$. Grumo Cesare Varasi.}

P.S.-Chamberlain has just told me that my bor has arrived. I thank you that it has not happened otherwise. ${ }^{16}$

Up to this time Vanini and his friend seem to have been well satiafied with their reception and entertainment in England. They were hospitably entertained by the two archbishops, and each of them was expecting a benefice. They had evidently believed that their zeal for protestantism would have led to some liberal preferment; and it is by no means improbable that, had their expectations been fulfilled, their faith would have been confirmed, and that Vanini, instead of perishing at the stake at Toulouse, might have lived and died a member of the church of England, and might probably have persuaded himself and his patrons that he was actuated by no other motive than that of zeal for the trath. Bat the benefices did not come. To do Abbot justice, notwithstanding his narrow puritanism, he never soems to have been very eager after 'convertitoes' (as he calls them in a subsequent lotter) from the Romish faith, and soems always to have had a shrewd suspicion that they were looking after the loaves and fishes rather than after the word of life; while Tobie Matther, who was more of a statesman than a divine (though a bitter persecutor of recusants), had no fondness for foreign converts, and still less anj intention of paying them for their change of opinion. Vanini was beginning to be impatient for a benefice, and Giovanni Maria found Bishopsthorpe dall. A letter from Chamberlain to Carleton, of 14 Jan. 1612-13, first makes known to us the discontent of the frisrs :

... Your Italian friar was with me this other day with a long dis. contented discourse for want of money and that he was sometimes fain to make his own bed and sweep his chamber, things he was never pat to in the place whence he came. I advised him the best I conld to patience, and told him that seaing he was well provided for food and raiment he might fashion himself to endure somewhat per amor di Christo. It seems his companion Giovanni is no better pleased in the North, for

Le Cal bori. 151, No. 14. The name in this letter which I havo printed as Chamberinin, is given in Palumbo's book es Ciaberth-en impossible nemo, at leant for an

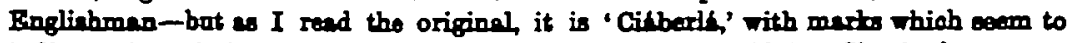
indicato abbreviations over the ' $\mathrm{g}$ ' $\mathrm{so}$ that the neme woold bo 'Cinmberien,' a not improbable mode of spelling Chamberiain for an Italian. In writing that ho hed not yot seen Chembertain - whoso lotter of 17 Jane, 1612, certeinly implies that ho hed wen the triars, and who, indoed, wo can hardly suppose wovld here been so neglectfol of Carleton's wighes es not to bave risited them as soon as be retruned to LondonI take it thet Vanini's meaning is that he bed not seen Chamberiain since the receipt of Wake's ' etter of last month.' He had probably only just remed to Lambeth trom Croydan. 
he prote lately to him that his patron the Archbishop was strettissimo di danari and that they lived not in citieg nor torns, but in villa, and thereupon subseribed his name Johannes in Deserto. ${ }^{17}$

This extract from Chamberlain's letter is translated at length by Signor Palumbo (p. 14), but he has not read the first few words accurately, for he translates them, I due frati italiani da roi raccomandati vennero oggi da me, whereas it will be seen that it was Vanini alone that called on Chamberlain, his companion being still at Bishopsthorpe. ${ }^{18}$

The presence of two Carmelite friars, professed converts to the reformed faith, and the fact that they had made public abjuration, and subsequently preached in the Italian charch, were of course well known, and could not but have been very distasteful to the anthorities of the church of Rome, and it is probable that at an early stage of their visit efforts were made to increase, or perhsps arouse, their discontent, and to induce them to return to the bosom of the church. Their movements were carefully watched by the emissaries of the Spanish ambassador, Zuniga, whose house was the focus for intrigues of every sort for the furtherance of the faith, and who about this time was detaining as prisoner in his house a converted Italian priest, who had come to England for refuge, as appears from a letter of Abbot to the king, of 17 Aug. 1612. But the immediate agent in the matter was the chsplain of the Venetian ambessador, Hieronymo Moravi, who now appesirs upon the scene, and who seems to have played an important, though rather mysterious, part in the subsequent adventures of Vanini in England. Moravi is mentioned by name by Vanini in the 'De Admirandig Naturae,' p. 217. He is there described as 'a most excellent and very learned man, who was my confessor during my stay in London.' I have not found any mention of his name in the letters in the Record Office; bat it appears from a letter of Abbot, of 16 March 1613-14, that the chaplain of Foscarini had admitted to him that ' now a year ago Julius Cresar upon his knees did beg of him to be

${ }^{17}$ Cal Lrii. 167, Na. 18; Cout and Timas of James $I_{1}, \mathrm{i}$ 155, 158. This letter is datod 14 Jwn. 1619, bat is alearly 1618 , cocording to our reokoning, treating the jear as beginning on $1 \mathrm{Jan}$. There is mnch (almost inovitable) contusion in the Caloudars, in the arrangement of lettens dated in Januery, Febratery, end March, as the writers nem sometimes to have used the legel, somotimes the common, year. Conso-

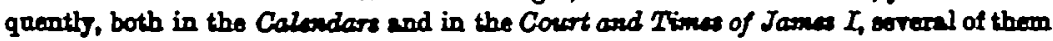
coecur out of thear proper pleoe, and a year oarlier then thoj should da. $\triangle$ caretal considaration of these, howerer, hes ensbled me to arragge them in their proper arder, and to aseribo to them their true detes.

1s Mr. Oven, still poesensed with the ides that Chamberlein lived at Canterbury, paraphrases the statement in tho letter as tollows: 'Tho day stter, Sir — Chembertain wroto to Bir Dedloy Carloton that his two protegites [sic] vero como to Cunterbury to find him. They were in great diffealties, which ho bad tor the time relioved' Ho hes immediately betore refarred to a lettor of $13 \mathrm{Jan}$. 1618, trom the archbishop to the bishop of Bath; this lettor, borrever, was not mont a year lator, ie 18 Jan 1613-14. 
a means to the Nantio living at Paris to write to the pope that a pardon might be procured to the two friars for leaving their order; which sccordingly he did.'

Bat as yet Abbot was quite answare that his gaests had begun to be dissatisfied with his entertainment. In a letter to Carleton, dated 24 Feb. 1612-13, he writes:

The two honest men whom the last year you sent unto me do very well, and 29 I trust receive nothing but contentment. ${ }^{19}$

In the meantime Giovanni Maria, who had probably not yet given up hopes of a benefice, had written a Latin poem upon the marriage of the Princess Elizabeth with the Connt Palatine. The marriage took place on 14 Feb. 1613, and the poem would be printed sbout the same time that the other 'Epithalamis ' appeared, namely, in February or possibly a little later. It is from this poem alone that we learn the surname of the anthor, or at least that by which he passed in England, for his christian names only are mentioned in the correspondence. A copy of the poem is in the British Museum, and the following is the title:

Do anspicatissimis nuptiis inustrissimi Principis D. Friderici seari Bomani Imperii Archidspiferi et Electoris ec. Comitis Palatini ad Rhenum Drcis Bavariae, \&c. cum illustrissims Principe D. Elizabetha serenissimi Magnae Britannise de. Regis Filis anigenits Poems.

Anno Domini 1618.

It has no printer's name or place, bat the suggestion in the catalogue of the British Museum is that it was printed in London. No entry of it, however, appears in the Registers of the Stationers' Company. The book is a small quarto, the pages annumbered; it commences with a brief dedication in praise of the elector Palatine gigned Joannes Maris Franch. Then follow fifteen pages of hexameters, ending with an epigram of twelve lines in elegiacs.

Although dealing in terms with classical mythology, yet it is really directed to a large extent against the church of Rome, and lest the allegorical references ahould be misunderstood, the anthor is careful to make his meaning clear by his marginal annotations. Thas to the lines

Quippe cohors scelerats specu Phlegethontis iniqui Exilit atro,

the marginal note is:

Innuit ad Iesaitas et trangfugas qui ex orco mittontar ad seditiones in Angliam infernalibus armis, nempe igne sulphure de.

And to the line

Est pis credulitas dictus temerarius error,

" Cal lodii 171, No. 39. 
the note is :

Quis in novis articulis ab ipsis fundstis cum destitunntar a scriptura dicant est Pinm credere.

Another note is:

Praocipua ars Antichristi est simulare se Dei adrocatom.

The poem, as printed, consists of one book only; but it appesrs that the anthor had written three books, and that his friends were so much pleased with it that one of them, Samuel Hutton by name, translated the whole of the three into English, and the translation was published about 7 June in the same year, on which day we find the following entry in the Stationers' Registers :

7 Junii Master Elde Entred for bis Copie under th[e h]ands of Master Nydd and Master Warden Hooper a booke called ' of the most Auspicatious Mariage betweene the Connty Palatine and The Lady Elizabeth' Three bookes composed in Iratyn by Master Johannes Maria de flannchis and translated in to English.

A copy of this also is in the British Museum. The title is as follows :

Of the most anspications marriage betwixt the high and Mightie Prince Frederick Connt Palatine of the Bhine chief server to the Sacred Roman Empire Prince Elector and Dake of Bavaria \&e. and the most illustrious Princess the ladie Elizabeth her grace sole daughter to the high and Mightie James King of Great Britain \&c. In iii Bookes. Composed in Latin by M. Josnnes Maria de Franchis and translated into English. At London. Printed by G. Eld for William Blaincker, and are to be sold in Fleet Lane at the sign of the Printers Press. 1618.

The volume consists of eighty-eight pages in all, eight at the commencement and three at the end annumbered, and seventyseven numbered. It is dedicated by the author to Charles, Prince of Wales, and the following is an extract from the dedication:

At the first I intended to have only a ahort and ordinary Epithalaminm, but afterwards bsving considered better of it, I found it much fitter to divide it into three bookes. The first Booke I sent to the right Boverend Father the Lord Archbishop of York who presented it anto the King. ... At length some of my friends bsving received this Poeme printed it being delighted with the novelty of the matter. . . . At the first it grieved me a little that my book being not fully perfected should be printed; but at last heving no desire to hare it printed again after that the solemnities Prere ended some of my friends began to importune me that I wonld impart my book nato them. I being essily overcome with their arging yielded unto their requests. This booke they have now translated into English, to the ende that the ladies may be partakers of this corions symetrio. This book I offer up to your Highnesse of whom I have heard many honowrable relations at the Right Reverend Father in God my lord Archbishop of Yorke's house. 
At the end is a short poem addressed to the Princess Elizabeth signed ' Semuel Hatton,' who seems to claim to be the translator. The name of Samuel Hutton does not appear in the 'Dictionary of National Biography,' and I have failed to find any notice of him. There was, however, at this date a prebendary of York of this name, a nephew of Natthew Hatton, Tobie Matthew's predecessor in the archbishopric, by whom, on 4 Feb. 1602-3, he had been collated to the prebend of Olleskelf, which he beld until 27 Nov. 1628.20 $\mathrm{He}$ is probably the author of the translation, which is the merest doggerel. A single specimen will suffice:

Frr sons of Jove, Earth tooke the slaves of hell;

Babell was tarmed a Reverend Sanctuary ;

Idolatry Devotion; high pride Zeal;

Rash error a religions credulity;

Hypocrisie was called laprs complement:

Thus every vice got virtue's own accent.

I now come to the question whether Vanini's companion may not have been the Josnnes Maria Genochius or Ginochins, who, as he tells us in the 'De Admirandis Naturae Arcanis,' accompanied him to Germany, and was with him at Strasburg when they embarked on the Rhine together. Genochins was at first unwilling to start, having seen a crow, which, as he thought, portended shipwreck. He here describes Genochius as praeclarissimus theologus, and mentions him with great praise in several other places-one in the 'De Admirandis (p. 160), where, discussing evergreen and decidnous trees, he cites, but dissents from, the opinion of ' Josnnes Maria Genochius Clavaro-Genuensis Philosophoram praestantissimus' that the cause of evergreenness is that evergreen trees caeteris calidiores sunt et sicciores. Another mention is in the 'Amphithestrum ' (p. 304), where, discussing the problem of reconciling the existence of evil with that of a Divine Providence, he s8ys: Coeterum qui omnirem optime de hoc argumento scripserit, est Dominus Joannes Maria Genochius Clavaro-Genuensis, vir sane Reipublicae colendissimus, in suo celebri opusculo de Gratia et lib. Arbitrio. Now the friar who accompanied Vanini to England is generally called in the letters simply Giovanni Maris : once, however, in the letter of Chamberlain of 11 March 1613-14, Giovanni Battista, either a mistake for Giovanni Maria, or showing that his fall Christian name was Giovanni Battista Maria. But in the tranglation of the Latin poem which he wrote on the marriage of the Princess Elizabeth with the Elector Palatine, he is called Josnnes Maris de Franchis. It may be said that this is inconsistent with his being the same person as Genochius, but this is not, I think,

- Lo Neve's Pasti, edited by Ekrdy, iii. 2020; Hutton Corropondence (Burtees Society). Pp. 13, 230. Ho it, no donbt, the person of thet neme tho took his degree of

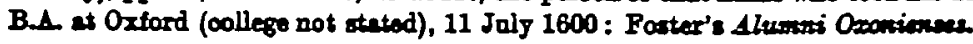


conclusive. The poem is a strongly protestant production: the pope is branded as Antichrist; yet at the very time of the pablication of this poem it is certain that Tanini and probable that both the friars were planning a return to the continent, and a reconciliation with the charch of Rome. It does not therefore seem improbable that in England he may have published his poem under a feigned name so ts not to hinder his return to his own conntry if his hopes of a benefice in England turned out to be rain. Gioranni Maria was, as appears by the letters, younger than Fanini, and it may be thought that the language which the latter uses of Genochius is inapplicable to one who, at the date of the publication of the 'Amphitheatrum," was certainly ander thirty years of age.

I have searched ineffectually for any trace of the treatise on grace and free will which Tanini states to have been written by Genochins. I have, however, found a notice of the man himself in the 'Athensenm Ligusticum ' of Oldoini (Perusiae, 1680, p. 358), where the following brief account is given of him :

Joannes Maria Ginoochius of Chiavari, a pious priest, a learned theologian, a zealous and eloquent preacher, and a poet of no common merit, published at Perpignan in 1620 'Cantica Centum Spiritualia,' in praise of the Blessed Virgin, in various metres. He also adorned the coronet of George, Duke of Centari, with a poem.

Oldoini then refers to the 'Bibliotheca Mariana' of Hippolytus Maraccius (Romse, MDCXLVII, Pars Prima, p. 756), where there is a similar statement, only making no mention of the poem upon Georgius Dux Centurionis. Genochius is also mentioned by Jöcher, who simply quotes Oldoini as his anthority. No copy of either of the books of Grenochius is in the British Musenm, and I hare been anable to meet with them. It would be interesting to compare them, especially the poem upon the Doke of Centuri, with the Epithslaminm. Such a comparison might assist us in coming to a conclusion whether Giovanni Maria de Franchis was identical with Joannes Maris Genochins. The very meagre accounts of him given by Oldoini and Maraccius are in no way inconsistent with the opinion that he was the companion of Vanini and the anthor of the Epithalaminm.

On 11 March 1612-13 Chamberlain wrote to Carleton a letter which contains a reference to the Latin poem :

.. . Your Friar Giovan Battista (that is with the Archbishop of York) hath published a Latin poem upon this late marriage of the Lady Elizsobeth with the Palsgrave and sent them to present to all his friends in these parts. The verses seem good, but the Invention old and ordinary and his Epistle to the young couple is altogether built upon a fabalous friarly tradition." 
Among the best known of the Italian residents in England at this time was Gioranni Francesco Biondi, a convert to protestantism, not less distinguished as a diplomatist than as a writer. ${ }^{22}$ He also was a correspondent of Carleton, and kept him well informed of various matters of interest from October 1612 to November 1613. Fifteen of his letters, all in Italian, are to be found among the State Papers in the Record Office. Biondi had of course heard of the arrival of the friars, and that they had been sent by Carleton; not improbsbly he had made their acquaintance, and had heard them preach at the Italian church. In a long letter from him to Carleton dated 17 March 1612-13 be writes :

As I believe your Excellency has not yet seen the little book of Signor Giovanni Maris, one of the two Carmelites sent here, I also send it to you. ${ }^{23}$

Although this letter contains no other reference to either of the friars, it mentions a curious and interesting fact, not, I think, elsewhere recorded, and hitherto annoticed, relsting to the well-known Oxford 'Epithalamis ' on the marriage of the Princess Elizsbeth, a copy of which he sends also to Carleton, and concerning one of them he writes : 'The Spanish ambassador makes great complaints, and his people say that they [i.e. the 'Epithalamia '] will all be burnt, which I do not believe.' I have examined four copies of these 'Epithalamia,' with a view of ascertaining whether the Spanish ambassador had a sabstantial grievance, and whether any steps were taken to remedy it. I find on the reverse of folio $F \mathbf{B}$ (printed by mistake E 8) in two copies of the book in the British Musenm (1213, 1. 9,

- See his life and a list of bis worts in the Dictiomary of National Biography. Signor Palumbo erroneously states that he socompanied De Dominis, archbishop of Spalato, into Englend, and thon apostatised. In teet he had sottled in England and become 2 protertent in 1609 , seven years before the arrival of De Daminis.

- Signor Palumbo hes strengely misunderstood this lettar. Ho writes: ' G. F. Biondi, when sending to Carleton the Epithalaminm written by the companion of Vanini and speaking of the spostary of these two triars, stetes that the Spanigh am. bassador mes in great tary apainst Vanini and his ac0omplices threatening that they should be all sent to the steke.' But the passage to which he refers hes notbing to do with the triars ar the operetta of Giovenni Maria, but refors to the Oxford Epithalamia, and the worde given by Palumbo in inserted commes, "che sarebbero tulti mandati al raga, ars certainly not to bo tond anywhere in tho lettor, which it secoms clear that be hee not read, bot hes contented himself with readiag (and misunderstending) the summary given in the printed Calondar, which is as follows (rol. lrxii. no. 80, 17 Mer. 1613. Giov. Preno. Biondi to Carleton): ' His [Cerleton's] condact in Venice mach praised by the Venetien $\Delta$ mbesendor in Englend, who is not popalar. Tho King faroura him becaues he protesses to be a Protestent, bat the Councillors ridicale him. The King not yet returned. The nobles eqgerly waiting tor office. Sends a rork of Giov. Maria, one of the two friers sent into Englend; also the Epithalamia [on the Paletine's marriagej written at Oxford. The Spanish ambeasedor complains of one of them, and his adberents say they will all be burnt.' Mr. Oren, who bows no more of Biondi than of Chambertein, as usual somewhat amplifies the statoment of Palmobo: - Fallen trom the good graces of English Protestanter Vanini and his companion had long beome lantbsome to the Catholice. A certain Biondi wrote to Sir D. Carleton on 17 Mnr. 1613 that the Spanish ambassador was in a rage against Fanini and his acconiplices on sceonot of his apostary, and threatened him with the stelea.' 
Tract 7 and 161, b. 43) the following ode signed ' $R$. Rands e coll. Trin. in Art. Mag.' :

\section{Ad Hispaniam.}

Mitte, niminm importuns, mitte, perfids,

Legationibus noris de nuptiis

Agere: labori sumptibusque si sapis,

Parcas, peracta cum scias omnia : minas

Prodesse credis, aut dolos? Clades tuas

Veteres loquantur arma, mentemque Britonum;

Para noram classem : secundó supplica

Iovem tuam, at coeptis tuis benediceret;

Aut potius artes Patre cum sancto novas

Meditare; classem mitte, mitte pulverem

Bombardicum, quis suspicamur ; Roms habet

Novas, inauditas petitas ab inferis

Artes nocendi : illinc novas technas pete

Et nuptias. Idola cum Christo, Bethel

Cam Bethsven constare qui possunt? pete

Romam ; illa consortem tibi dsbit parem,

Qualemque velles; nempe formarum ferax:

Quas si minus probas roga Papam, ut velit

Matare serum, non novo miracalo.

In my own copy of the book (formerly the Rev. W.E. Buckley's) this leaf is missing, but in the third copy at the British Museum (the Grenville copy, 17499) folio F 3 has been reprinted; the poem 'Ad Hispaniam' is omitted, and there are substituted for it sirteen inoffensive and commonplace elegiacs commencing

Ludite nune Hilares pullam deponite vestem Musea; pro tristi funere venit hymen.

On the reverse of folio $P$ in the two first mentioned copies there commences a poem entitled 'Prosopopoeia ad comitem Palatinum ':

I pete coniugium foelix foelicius illo

Quod, quae Teutonicis late dominatur in arvis

Austriscse generosa domas prosspis vestris

Dilectis potait thalamis, Germane, dedisse.

Hic tibi pro dote eximii numerantur honores

Divitiaeque suis quas Anglis mittit ab oris,

Et quse divitias superat celeberrima virtus,

Quse tanto foigore micat, miratus at illam

Non semel in thaiamos spretus roluisset Theras,

Non semel uxorem petiisset Gallus. At illi

Alter habendus amor restat simul altera sedes.

It ends on the next page (fol. P 2) with the following verses :

Gordius Hispano non est resecandus ab ense

Nodus, et alterius laetetar Gallis tredis.

Post tot neglectos remanes, Comes inclyte, solus,

Qui nodum solvas, et tanta trophaca reportes.

Gu. Crosse Suncti-JIariensis. 
In the Grenville copy, and also in my own, folio $\mathrm{P}$ has been reprinted, and instead of the 'Prosopopoeia ad Comitem Palstinum' are substituted eight feeble and commonplace elegiacs addressed 'Ad Regem,' with the cstchword at the end 'Vere' instead of, as in the original impression, ' Gor.' But, notwithstanding this, folio P 2 has not been reprinted, but in both the Grenville and my own copies the original four rerses appear, beginning 'Gordius Hispano non est resecandus ab ense.' In the Grenville copy I can find nothing to account for this, but in my own I find the following note on the flyleaf, in Mr. Buckley's writing: ' On P 2 at top some verses have been pasted over.' An examination of the page shows clearly that this has been the case, but unfortunately Mr. Buckley or some former owner has removed the paper that was pasted over the first four lines, and which no doubt contained the conclusion of the poem ' $\Delta d$ Regem ' beginning with Vere; of this a fragment containing a part of a aingle word alone remains. The conclusion to be drawn from an eramination and comparison of these four copies is clearly this. The Spanish ambessador had made complaints, as Biondi states, concerning the 'Ad Hispaniam ' and the 'Prosopopoeia,' but instesd of the volume being burnt as his people (i suoi) expected, the two obnorious pages were ordered to be reprinted, and inoffensive verses to be substituted for those which had given offence, and instead of reprinting $\mathrm{P} 2$ the first four lines were ordered to be pasted over, and when this was done the book was allowed to be circulated.x

At the date of Biondi's letter of $17 \mathrm{March} 1613$, the two friars, 80 far from having fallen from the good graces of English protestants, were still in favour, and there seems as yet to have been no suspicion that they were otherwise than sincere in their professions of adherence to the reformed faith.

In the summer of 1613, Giovanni Maria, having become tired of Bishopsthorpe, returned to London on the pretert that he was about to print some other book-possibly the English translation of his poem. He asked to be placed with the bishop of London, and this was agreed to, but, as it seems, the bishop was unwilling to receive him until he had been discharged of an English converted Jesuit, of whom he was then the somerhat anwilling host. On his arrival in London, he was lodged in a prirste house until the bishop was ready to receive him. While there he fell sick, and, in order that he might heve the company of Vanini, was brought to Lambeth and lodged there, at the expense of Archbishop Abbot, ' in an honest house,' where he remained antil shortly before 10 Feb. 1614.

" I hare been meble to find ang further roferenco to tho compleinte of tho am-

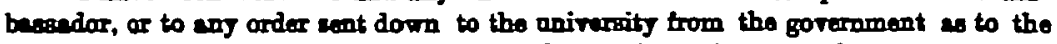
book. It world be interenting to know whether in the archive of the miversity any rech order is to be found 
In the meantime, Vanini had become heartily tired of Lambeth und of England, and, as we hare seen, was taking steps privately to obtain pardon for himself and his companion from the pope for lesving their order, through Morsvi, whom he begged to write to the nuncio living at Paris, for this purpose, and one hundred crowns were sent to the nuncio to pay for the pardon. But he still professed himself a protestant, frequented prayers, received the communion in the chapel at Lambeth, and attended the sermons in the Italian charch. On 25 Nov. 1613, we find the following in a letter from Chamberlain to Carleton :

I know not how yt comes to passe but the two friers you sent over are in poor case, and have been both lately sick specially the younger that was $\mathrm{w}^{\text {th }}$ the Archbishop of Yorke but wesrie of that place and belike lingering after this goode towne could not agree with that air forsooth, so that he was appointed to the Bishop of London who making stay to recesve him till he might be discharged of an English converted Jesuit committed to him, he fall aicke in the meantime and the best relief I learn he found was that he was begged for in some churches and his companion goes up and down to gather the charitie of all their acquaintanos and well wishers.2s

About this time Vanini paid a visit to Cambridge, where 'he had good store of money giren to him,' and shortly after Christmas he went to Oxford, where he had more money bestowed upon him. There he confided to one who had formerly been a Roman priest, that he was in heart a papist, and meant before long to leare the conntry; he seems to hare spoken freely of his intentions, as well as 'undutifully' of the bing and 'unreverently' of the archbishop. His visit to Oxford was only a few months after that of Casanbon, and he must hare arrived immediately after the expulsion of Jacob the Jew, of whose stsy at Oxford and simulated conversion Mr. Pattison has given us so entertsining an account in his Life of Casaubon. It seems probsble from the mention of him in the 'Amphithestrum,' that Vanini had made his acquaintance in England."

Vanini returned to Lambeth shortly before Jan: 22 ; a report of his imprudent language there was sent to the archbishop, whose suspicions had been already aroused by information that Vanini had written to Rome, and, as the archbishop rightly conjectured, with a view of obtaining absolntion for his departure from his

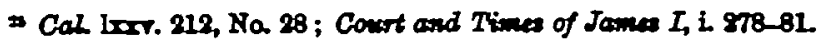

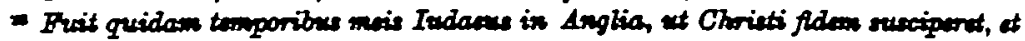

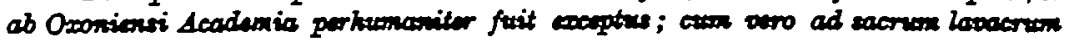

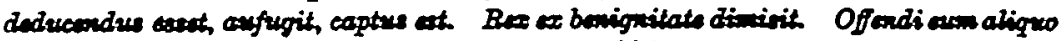

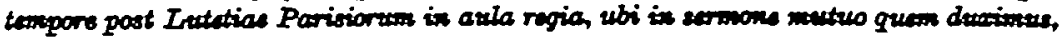

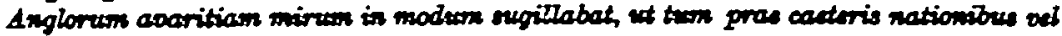

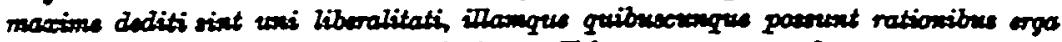

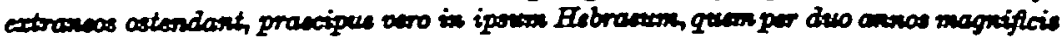

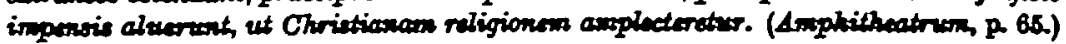


order. A watch was set apon the friars: they were found to be removing their effects from Lambeth, and were clearly preparing for flight. But they still made outward profession of protestantism, and attended the Italian services at Mercers Hall on Sonday the 22nd, when Vanini agreed to preach the following Sunday, having in fact made arrangements to leave England before that day. After service on the 22nd they were both separately examined and afterwards confined to their respective chambers, while Vanini was soon after removed to the Gatehouse at Lambeth. ${ }^{77}$ Shortly before 27 January 1613-14 Abbot wrote foll details to James Montagu, bishop of Bath, then in attendnnce on the king at Royston :

There is one thyng falen out here wherein I humbly crave his majestys direction as being in my opinion a matter of some importance. By motion from Sr Dudley Carleton at Venice his mato was gracionsly contented that twoe Italian Carmelite ffriers shold come into England who pretended to fly hither for their conscience. They came and after the abode of him here for a month or twoe the younger of them was sent to $m y L$ of Yorke where he was very well intreated for one year and since hath remayned at London, and in Lambeth detayned by sicknes that he was not placed in my Lo. of London's house, whither notwithstanding care this very weeke he hath been removed. The other also in my house being enterteyned with such humanity and expense as is not fit for me to report, but I am sure it was too good for him. Theise men in the Italian churche at London publiquely renounced their popery in a solemn form, preached there divers times, frequented our prayers and participated of the Eucharist after the manner of the Churche of England sererall times. And yet it now appeareth they have all this time ben extreamely rotten. About 3 months since I by a secret meanes undenstood that the elder of them had written to Rome and I had cause to conjecture that it was for an absolucion for their departure from their order. I caused one to speake with him thereabout but he gave such an answere as I cold not contradict bat yet thought fitt to carrye an eye over him.

But now about 16 dayes since he asked lesve of me to go Oxford which I granted unto him and tooke order thst he was furnyshed with money to bear hil charges. Being there he was most humanely entreated and had some money given him to the value of twenty markes as he sayeth but as some from thence write to the somme of twenty poundes. There to one or two who had been in Italy he let fall divers words declaring his dislike to our religion and shewing that his mete had not dealt bountifally with him, and that I had not shewed myself liberall unto him

\footnotetext{
27 There can, I think, be little daubt of the correctness of the dato ebove given for the arrest of Vanini. Abbot's lotter to the bishop of Bath, though undatod, is elearly written sboxtly before $27 \mathrm{Jan}$. and speals of the first oreminetion of Vanini as on

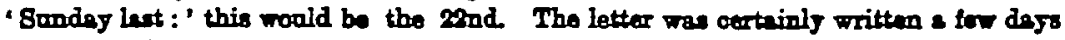

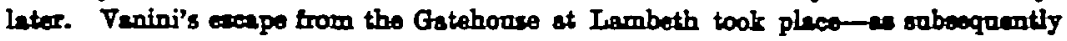
2ppear-shortly before 16 March. He tells as thet he was imprisoned for forty-aine daye If his imprisonment commenced on $24 \mathrm{Jen}$, the forty-nine degs wonld expire on 14 March.
} 
together with divers other both unfitt and untrue speeches without honesty or shame. And divers intimacions he gave of bis purpose to withdrawe himself out of England wyth all speed : well now he sayeth shold not have ben without the leave of his mate.

These thyoges are advertised unto men from Oxford twoe or three severall wayes, Whereupon at his return causing him to be observed I found by his secret conveyance of some things out of my house and by the recourse of both of them extraordinarily into London thst there was great cause to suspect thet they intended to be gon. And hereupon in a fair manner I severed them both exch from other and examined them aparte: where at first they seemed to contynue constant in our profession though upon a second examination it proved otherwise. By one passage your Lordahip shall judge of the strange wickedness of the men. On Sunday last the elder of them upon his examination ander his hand did say quod renunciasset Papismo et pontificiis opinionibus; st se velle vivere et mori in fide Ecctic Anglicare, yesterday this being arged unto him and not seeing his former examinstion he said it was true quod Papatui renunciasset quia non erat verisimile se unquam futurum Papam. And touchingopiniones Pontificias he expounded it that si quis inter Pontificios opinaretur eum unquam in Papatum promerendum, he did disclsyme that from being a good opinion. And for his living and dying in the faith of the Church of England he expoundeth that to be the faith which was here a hondredth or two hundreth agone.

He now also sayeth that he was never otherwise than a Papist in his faith; and that their coming into England was for nothing bat to erayd the hard measure which their Conncell used to them and because they heard that strangers were entertegned here with great humanity. Such leath been the strange dissimulacion of the men if they have all this while been Papists in their hearte, but I hsve reason to suppose that some instroment of a sovereign Ambassador hath been tampering with them, and hath both with money and faire promises corrapted them. ${ }^{23}$

On 27 January Sir Thomas Lake sent a copy of the archbishop's letter to Sir Dudley Carleton, accompanied by the following letter :

My lord Ambassador,-By this enclosed copie which is of a lettre of my lo. of Cantorburies to my lo. Bishop of Bath following his maj: at Court your lo. shall percespe what is become of your two friers you sent us. I am commanded to send to you, and to require you to advertise what you have heard or observed of their caryage here or of any traffike they have had there since their being in England. Their escusations of their submission here and abjuration are very grosse. Bur I never had anie great confidence in renegados there be few that do it upon religious respect but on worldly consideration. I fear much my Lo. of Canterbury hath of our owne conntry very many proseleytes wherain he much glories that be of none other temper for I marke that as soon as ever they come over to us they are gredy of wiffes and benefices. ... .

From the Court at Royston this 27 January, 1613-14.

Thos : Iuase. 20

- Cal. Lervi. 221, No. 9, L

- Cal lurvi. 221, No. 9. 
A few days later Chamberlain wrote to Carleton a letter containing the following passage:

I heard lately that the two friers you sent over are returned to their vomit and prove notable knaves professing now that they were never other than Romish Catholikes wherein they will live and die and that theyre come hither and theyre dissembling was only per guadagnare et fornicare they have solicited theyre return and to be received again into theyre mother church by the Venetian ambassador here and other meanes at Bome. How their jugling csme out I know not but my L of Cannterburie hath committed them to sefe custodie and makes it appear that want woold not drive them to any extromity for besides victum and ves. titum they have hed fifty pounds in money of him thitty of the bishop of London besides the Archbishop of Yorks the bishop of Elyes and other bishops bountys of whom they were ever begging as well as of meaner folks as $\mathrm{Sr}$ Harry Franshswe and myself and they had of Burlamachi ten pounds of the Prince Palatine and the Lady Elizabeth ten pounds apiece with I know not how many more we shall hear of hereafter for I had this bat at first hand of an Italian that says he spake with them since their restrainte, as I understand more of them you shall hsve it. . . .

8 Feb. 1618-14.00

A fer days after the date of the last letter Giovanni Maria escaped from Lambeth, where he had been placed by the archbishop in the house of 'a sworn servant of the hing, 8 warder of the Tower.' He let himself down from the window at midnight by means of his sheets, which be tied together, and fled to the house of the Spanish (or Venetian) ambassador, where he remained some twenty days, and then was conveyed out of England. On 10 Feb. Chamberlain wrote to Carleton and informed him of the escape :

I have been lately twice or thrice with the Bp. of Ely. . . . He confirmed the revolt of the friars trom the king's own mouth, where he first heard it, and says he never had any great mind to new and sudden converts haring had many trisls of their lasvery and inconstancy. I ander. stand one of them hes escaped to the Venetian ambassedor's."

On 18 Feb. Biondi writes to Carleton, 'Gio. Maria is fled, as your Excellency will have heard ; the other is in prison, snd ready as he says for martyrdom. I pray God it will be granted to him, bat I doubt it, for his Majesty is more religious than politic.'

- Cal lavi 292, No. 18

- Cal. bavi 228, No. 20. The santenoo immodistaly following the sbove extract

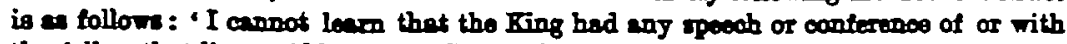
the fellow that lies at Aldermen Bollew, end his return in not expeoted till towards his dey the'24th of Warch' I was at firt disponed to think it reforrod to Giovanni Marie, asd thet Aldormen Bolles' wes the 'honest house at Inaboth' whare, es eppears bJ s eqbeequent lettar, ho hed lodged. But as he had af lete been in tho house of a wrom warder of tho Tower, and hed exped betore this lottor was written, I think it most probablo that the sentence refers to some other person.

I Cal. Lror. 274, Na. 36. This letter is displeoed, and inserted in the Calondas under dete 1615 instead of 1614, to which it cloarly belongen 
Bat Vanini was in no danger of martyrdom. He was imprisoned in the Gatehouse at Lambeth for a fortnight, and then brought before the ecclesiastical commission. There he was censured, excommunicated, and sentenced to imprisonment daring the king's pleasure, and the help of the temporal sword was implored ' that he might be benished to the Bermudas, there to dig for his living.' Fortunately for Vanini-or perhaps unfortunstely, for the Bermudas might have been better then the flames at Toulouse -he, like his friend, found the means to escape soon after this sentence was pronounced, and before any steps were taken for carrying it into erecution. He was assisted in his escape by a Florentine-a servant of Lord Vaux-employed probably either by Moravi or the Spanish ambassador. The keeper of the Gatehouse was said to have been corrupted, but it is not improbablo-as no one sems to have ben punished for assisting his escape-that it was connived at by the suthorities, for to send a foreigner to the Bermudas or Virginis for no other offence than abjuring protestantism would have been a high-handed measure which could hardly have failed to irritato and justly - the Spanish ambassador, whom James was at all times desirons to conciliate.

As the friars had been protegés of Carleton, Abbot thought well on 16 March 1613-14 to write to him a long and most interesting letter, with foll details as to their conduct while in England and as to their escape. It is partially written in cipher (which is, however, deciphered) :

Your letter of the 28th of February is lately come into my hands and thereby I perceive that which formerly I heard from the king himself that Sir Thomas Lalke had advertised you of the ill demeanour of the two Italian friars. There is no wiseman but must commend your endeavours and not judge of them by the event becsuse you are a man and not in the place of God who only knoweth the heart. I cannot deny but that for outward show they did bear themselves well until January last, although for some months before I $89 \mathrm{w}$ some private inkling of the tratiching of the elder of them by letters to Bome which I laid by in my memory, but did not very hastily give credit thereunto.

The manner of their entertainment here was thas. For about two months they remained in my house together, being lodged apparelled and dietted at my charge. The younger of them was praffered a place in Oxford where he should freely have had all things requisite for him to follow his study, but he desired rather to go to my Lord Arohbishop of York which was yielded unto so that he was furnished with money thither, and there he remained for a year being fully provided for. In the mesntime he frequanted pragers, received the Communion, published a book in verse on the marriage of the Count Palatine, wherein be branded the Pope to be Antichrist. At a years end he degireth to return to Landon under colour of printing something else, moreth the ling that he might be placed with my Lord of London which is yielded unto. But before the eccomplish- 
ment thereof, he falleth sick and lieth in a private house in London where he had physic freely and much money was given to his brother for him, and apon his amending, for the company of the other, wes brought over to Lambeth, and being lodged there in a honest house was msintained at my charge till his final departure.

The elder from the beginning to the end was held in my house dietting at my own board or if that were fall at my stewards table had lodging bed and utensils for chamber provided for him as well at Croydon when I lsy there in the summer as otherwise at Lambeth so that begides meat and drink and lodging, they two in the time they were in England had in money from me for spparell and other necessaries abov lis besides such money as the younger had from my Lord of York and more than six seare pounds which came to their hands otherwise as may be showed by the particulars. In the time of his abiding with me he frequented prayers, received the Commonion twice or thrice in my chapel, preached divers times at the Italian Charch in London especially at his first coming as his brother also did.

Before Christmas I gave him lesve to see Cambridge where he had some good store of money given anto him. After Christmas last I parmitted him to go to Oxford whare he had mare money bestowed upon him. There to one who had formerly been a Roman priest and lived much in Italy he opened himself that he was in heart a Papist and meant before long to fly out of the kingdom. He gave to some other persons semblances of the like and could not forbear to speak undatifully of the hing and unreverently of me, uttering many lies concerning his entertainment by me. All which things being by letter made bnown anto me I secretly learned that they had conveyed divers things of their own out of my house and questioning them for it had shifting answers for the time. In their first examination they arowed their constanci in our religion and strongly denied any purpose of flight, which indeed they carried so covertly, that on the day of their apprehension they were at the sermon in the Italian Church and the elder of them did promise to preach there the next Sunday when his purpose was to be gure in the meantime as since he hsth confessed.

From the time of their first examination they were committed to their lodgings severally. Upon the second touch they discovered themselves to be resolute papists so that never did I find in all my life more impadent and unworthy varlets. It is beyond the wit of man to conceive the hight of wickedness wherennto they were grown. I will give you a short example. The elder of them had said in his first examination Quod in ecclosia Italia Londinonsi renuntiasset Papismo et Pontificits opinionibus, ot se vells vivere et mori in fide Ecclesiae Anglicanas ; et quod si ad vomitum rediret, moreretur haberi singularis hypocrita, et is cuivus cor Sathanas cocupavit. In his third examination he explained all this with a strange qualification that by Papismo he meant Papatui, and that he had renounced any hope that ever he should be Pope, and for opiniones Pontificias his intendment was that if any of that side did think that ever he should be elected Pope, he disliked that their conceite He would live and die in the faith of the Church of England, that is the same faith which the Church of England possessed a hundredth or two handredth years ago. 
And if he did redire ad vomitum, that is of his evil life, or merely behaviour etc. which he might well mean, if Ascanio the prescher of the Italian Church do say true, for he hath long kept Julias Caesar from preaching in his charch, as taking him to be of no religion, but a profane person, a filthy speaker and a grosse fornicatour, and could not be indaced to think of him otherwise, although many of that congregation were sore offended with him for the same, which now they see was not without ground. And I had found both by the books themselves and by their own confession that the greatest matter which they have studied for many months past were the works of Petrus Aretinns and Macciavelli in Italian so virtuons was their disposition.

I imagine by this time you will ask of me two questions, first what is become of them, and secondly what hath been the resson of their desertion. To the former I answer that the younger of them being kept prisoner in his chamber at Lambeth Towne in the house of a sworn servant of the lings a warder of the Tower did abont midnight break forth at a window and tying his sheets together, so escaped. I do guess where he lay hid Ye Sp: Amb

for 20 dags that is in the house of 94 bat since as I anderstand he is conveyed out of England. To keep the other safe I sent him to the Gatehouse where when he had remained about 14 days he was convented before the Commission Ecclesiasticall and there censured by excommonication imprisonment during the lings plessare and the imploring of the help of the temporal sword, that he might be banished into the Barmudas there to dig for his living. But before the accomplishment hereof, by corrupting of the keepers, as I suppose, and by a trick played by some other Italian, he hath broken prison, to the grest offence of the kings majesty which hath laid up diverse in sefer custody.

The first overtare to their desertion came as I think from the

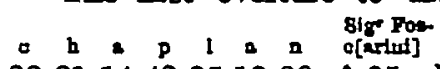

83911442851039 of 95 who is a very lewd man and bath done here many ill offices. This party hath confessed to me that now a jear ago

Julias Cresar upon his knees did beg of him to be a means to the 100 Purte Te pp

living at 177 to write to 230 that a pardon might be prooured for the two friars, for leaving of their order, which accordingly he did. And Jotins Caesar hath confessed to me that this was effected, and by the means of

Ye Nantio

the party above named a hundred crowns were by him sent to 160 at Parts

177 to pay for the said pardon. So that by this you may see that the friars were splendidly provided for here, when besides their visticnm to convey them into Italy they hsire so mach money to spare to send ont of Ye8p:

the realm before them. But 94 since his coming into England hath much bestirred himself in this and the litre businesses which I conceive will procure him a rappe here before it be long for the eje of the state is upon $\mathrm{Y} \bullet \mathrm{K}$
of $8 \mathrm{p}$ :

him. Ho hath much money from 124 and corrupteth almost all that 
Ambr

come in his way. There is skant any $\mathbf{2 5 9}$ here residing but he winneth bis servants to his purposes as namely he hath gained the 249214418 it a Y YaPr.

1240 of 98 and the same domestic together with the 162 of 95 so that they are more his servants than the parties to whom they belong. The

$$
\text { hine ves. se LI of re }
$$

game laboureth in the house of 62 of 69 and divers other of 78.33

The 'works of Petrus Aretinus and Maccisvelli' which wert studied by the two friars, and which so scandalised the archbishop, were not, we may be certain, 'La Passione di Gesù,' or 'I Principe,' bat, of Aretin, either the comedies or the 'Ragionamenti,' and of Machiavelli, the 'Mandragola ' or 'L'Asino d' Oro.'

Chamberlain refers to the escape of Vanini in a letter written to Carleton the day following that of the archbishop (March 17):

. . . The elder friar that was in the Gatehouse 34 hath found the means to escape so that now they are both gone. The keeper is committed and a Florentine that serrs 3 the Ld Vaux is suspected to be privy to his escape. For my own part I am not sorry we be so rid of them, for though they were notorious rascals, yet I know not what we should have done with them, yet it was in consultation to send them both to Virginis but I see not to what purpose. . . .35

I find only one subsequent reference in the State Papers to Vanini and his companion. It occurs in a letter of Abbot to Carleton, of 30 March 1614 :

I know nothing of Signor Francesco Biondi bat good, and therefore I will hope the best. Bat hereafter we shall be wary how we hastily enter. tain the Convertitoes of that nation so inestimable hath been the hypocrigy and lewdness of the two Carmelites lately remaining with as. I by my last wrote $\mathrm{my}$ mind at large concerning them. ${ }^{36}$

When writing this letter the archbishop little thought that be was soon to entertain a 'convertito' of much greater importance, and one who would cause him much more serions inconvenience and annoyance than the two Carmelites. Marco Antonio de

- Cal lavi. 227, No. 18.

- Signor Palumbo talls as that the two triars were imprisoned in the Tower. He thinks he hes identifled the sotall cell, a very gmall, dark, cirouler room, too low for it to be posesible to stend upright in. And he draws a berroving picture of the anguish of il povero fllosofo at the silence and horror of the pleco donde non si weoiva che por

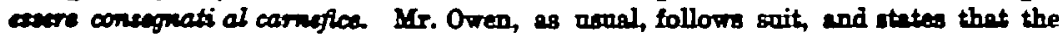
two triers were committed to the Tower.

4 Cal borvi 227, No. 49; Coust and Tinues of James $I$, i 23. This lotter is ther undated, but is placed betwean a letter of Carleton of 12 March 1612-18, and ane of Chemberlain of 25 March 1613. The word ' trier ' is strangely enongh printed 'Tajlor,' oo thet it does not seem, as printed, to have any reference to the triar.

- Cel lnii. 178, No. 97. This volume contains the documents trom January to Hag 1612-13, bat it is clear that this letter was written a jear later, and shoold have been inserted in vol. lxxvi., which contains the letters of that dete. 
Dominis, archbishop of Spalato, was already preparing to leave the church of Rome and to visit England, where he arrived in December 1616, and was forthwith handed over to archbishop Abbot for entertainment at Lambeth.

With his escape from the Gatehouse at Lambeth, Vanini disappears for a time from view. A few months later we find him in France enjoying the protection of the Marshal de Bassompierre, and probably receiving some consideration as one who had been persecuted in England for his attachment to the catholic faith. But catholic France proved in the end eren more inhospitable than protestant England. In the prison of Toulouse, after hearing the brutal and terrible sentence of the parliament, and whilst awaiting the flames which were to consume him a few days later, he may well have regretted the Gatehouse at Lambeth. His tongue was cut out, he was then strangled, and his body burnt in the Place Saint Etienne on 19 Feb. 1619.

The letters of Chamberlain and Abbot are not calculated to give us a farourable impression of the character of Vanini, and I am therefore glad to be able to conclude this paper with a fact which, I think, deserves to be set down to his credit. He was certainly disappointed with the result of his risit to England, but in neither of his printed works is there an unfriendly word relating to this country or to those with whom he came in contact here. On the few occasions that he mentions England in his writings, it is always with goodwill and sometimes with admiration. He praises our temperate climate, and says that he never felt it colder here in the depth of winter than at Padus and Bologna in November. He speaks of the mild disposition of the English, which he attributes, cariously enough, to their habit of drinking cold beer (frigida cervisia), and, as appears by the passage already quoted referring to the Jew Jacob, he writes with high praise of the liberality with which foreigners were treated in England. Even when he speaks of his imprisonment he utters no word of complaint. It is pleassant to think that he did not follow the example of Jacob Barnet in railing at his English benefactors.

Richard Coplegy Christir. 